IJ§ER

ISSN: 2149-5939
International Journal of Social Sciences and Education Research

Online, http://dergipark.gov.tr/ijsser

Volume: 3(4), 2017

\title{
Inscribed triumphal columns of Assyrian kings in Anatolia as a symbol of sovereignty ${ }^{1}$
}

\author{
Nurgül Yıldırım ${ }^{2}$
}

Received Date: 10 / 03 / 2017

Accepted Date: 12 / $06 / 2017$

\begin{abstract}
The main reason for the campaigns, battles and massacres organized by Assyrian kings for conquering Anatolia or at least taking the region under control has been thought to be the raw materials resources in Anatolia and the convenience of sea and land connections through which these raw material resources could be transferred. As of the beginning of 2000 BC, the policy followed by Assyria, which had been started with the commercial relations with Anatolia and in the period of Assyrian Commercial Colonies when mining reserves of Anatolia largely carried to Assyria, continued in a straight line without impeding the trade performed upon the consent of Anatolian kings. Being home to establishments that were politically, economically and socio-culturally different, and losing its civilization level with the increase of mass movements, Anatolia was ruled by small or large kingdoms which tried to exhibit Hittite characteristics in 1000 BC. In this period, Assyria that gradually gained power and tried to expand with the policy of western expansionism turned its face towards Anatolia once again to dominate on the path from being a kingdom to becoming an empire and to make this permanent. Accordingly, Assyrian kings left permanent marks on the lands they conquered during the campaigns to Anatolia. It was aimed in this study to shed light on the triumphal columns left by Assyrian kings in Anatolia after the successful campaigns by means of both philological sources and archeological finds.
\end{abstract}

Keywords: Neo-Assyrian, Neo-Hittite Kingdoms, Kurkh Monolith, Antakya Stelea

\section{Introduction}

Relations between Anatolia and Mesopotamia have generally been developed in search of raw materials or in the desire to seize the Anatolian lands and to have the permanent say in the Mediterranean trade. The first documents that started the preliminary history of Anatolia by shedding light on the Anatolian-Mesopotamian relations were the documents called šăr-tamhāri meaning

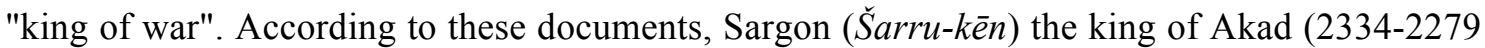
BC), embarked on an expedition to Anatolia. The reason for this expedition was that the Akadian merchants, who lived in the city of Purušhanda in Anatolia, seeked help from Sargon upon being harassed by the local people. A copy of Akkadian Sargon, first written in Akkadian, which was written in Old Assyrian, was found as a result of Kültepe excavations and brought to the scientific world by C. Günbattı (Günbattı 1997:131-155). The statement in the Akkadian Sargon text "I divided the Amanos Mountains into two and I had a monument built in there" has been accepted as the first known example of the victory monuments left by the Assyrian kings in Anatolia, which constitute the main head of this work, as the beginning of a tradition. The relevant part of the text is as follows:

\footnotetext{
${ }^{1}$ This article is based on a paper presented at the 3rd International Conference on Social Science and Education Research (ICSSER-27-29 April 2017) Rome, Italy.

${ }^{2}$ Asst.Prof. Mustafa Kemal University Department of Ancient History, Hatay, Turkey, nyildirim@mku.edu.tr
} 
Yıldırım, N. (2017). Inscribed triumphal columns of Assyrian kings in Anatolia as a symbol of sovereignty. International Journal of Social Sciences and Education Research, 3(4), 1112-1119.

${ }^{47)} \ldots \check{s} a-d u-a-a m H u-m a-n a m{ }^{48)} a-\check{s} i-n i-s ̌ u ~ a m-h a-s ̦ u-m a ~ k i-m a{ }^{49)}$ sí-ki-tim i-ba-ri-šu-nu șa-

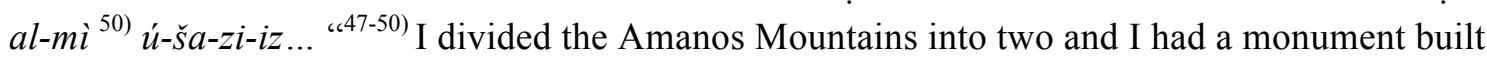
in there like a post..."

The period of Assyrian Trade Colonies, which started in the first quarter of the second millennium BC, showed that the relationship between Anatolia and Mesopotamia also developed through trade based on raw material resources. However, the relations between Anatolia and Assyria became more systematic, more comprehensive and more organized in this period. (Günbatt1 2011: 252-253-Özgüç 2005- Kulakoğlu 2011:40-51).

The cultural level of the peoples migrating to the Anatolian lands from the west during the Migration of Sea Peoples in 1200s BC was rather low. The destroyed central structure of Anatolia left its place to small kingdoms. Even though the Migration of the "Sea Peoples" influenced the Anatolian and Egyptian geographies in different measures, it greatly weakened or suppressed the great powers in this land, namely Hittite and Egypt. This made the expansion of Assyria easier, who wanted to dominate the land trade in Anatolia and the big sea trade in the Mediterranean by adopting an expansionist a policy. Assyria expansion, particularly in the ninth and eighth centuries $\mathrm{BC}$, was attempted to be prevented by the power of the coalitions which were founded by different kingdoms, lacking central authority in Anatolia. The Assyrian kings organized expeditions to Anatolia in order to disperse these coalitions, which posed a serious threat to them, and to make their sovereignty permanent. At the end of these expeditions, they had victory monuments built in, often in the form of rock reliefs, as a symbol of their dominance in the land they conquered.

\section{Assurnasirpal II/ Ǎššur-nāṣir-apli (883-859 BC)}

The Assurnasirpal II, from the first years of his throne, organized expeditions to disperse Arami tribes, who were becoming increasingly threatening in Anatolia, to reach the southern Anatolia and to benefit from the rich forests of the region. The Assyrian king Assurnasirpal (885859 BC) had a stela (Weinfeld 1999: 137) erected on the Amanos Mountains that symbolized his victory after a voyage to Que, which is thought to be an evidence of the region's importance for Assyrians (ARAB I: 16). The Kalhu tablets, which included the records of Assurnasirpal's kingdom's voyages in its 1st, 5th, and the 18th years, and the Kuruh (Kurkh) Monolith, which told about the 879th voyage year, made it possible to have information about the kingdoms established in Anatolia (ARAB I: 178). 
Yildırım, N. (2017). Inscribed triumphal columns of Assyrian kings in Anatolia as a symbol of sovereignty. International Journal of Social Sciences and Education Research, 3(4), 1112-1119.

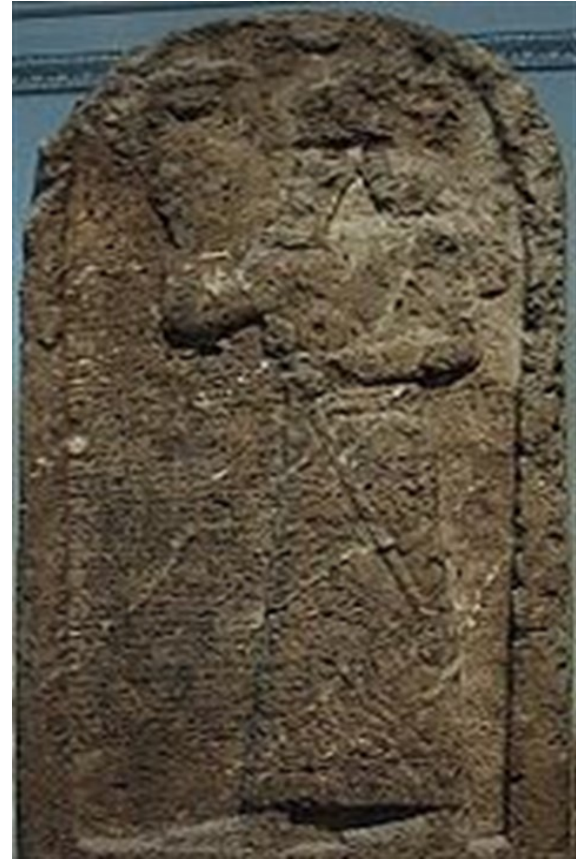

Assurnasirpal II- Kurkh Monolith (British Museum)

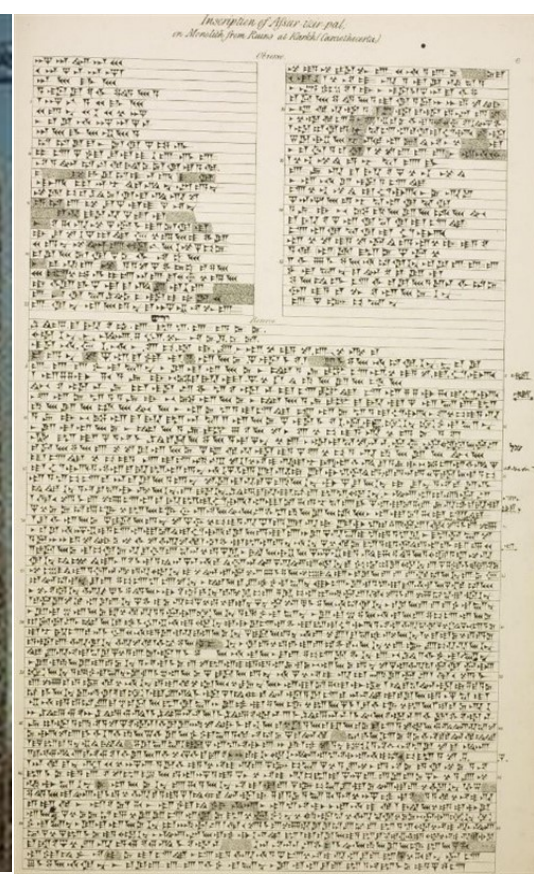

\section{Shalmanesser III/ Šulmānu-ašarēedu (858-824 BC)}

From his first year on the throne, the third Shalmanesser III had the records about the expeditions that he embarked in Anatolia and its close geography kept with great diligence. According to these records, he was interested in Anatolia and its close geography just like the Assyrian kings preceding him, and often organized expeditions to this geography. According to an expedition record belonging to the first year of his throne, he reached close to the Amanos mountains and a monument was built on the Lallar Mountain. (ARAB I: 201). From his first year on the throne, the third Shalmanesser III had the records about the expeditions that he embarked in Anatolia and its close geography kept with great diligence. According to these records, he was interested in Anatolia and its close geography just like the Assyrian kings preceding him, and often organized expeditions to this geography. According to an expedition record belonging to the first year of his throne, he reached close to the Amanos mountains and a monument was built on the Lallar Mountain. It is thought that Uzunoğlantepe (Ferhatl1) rock relief (Taşyürek 1975: 170), located to the east of today's Adana-Kozan road, can be dated to the Shalmanesser III period (Ünal 2006: 67102). Likewise, it is thought that a victory monument near Zincirli may have been built for the Shalmanesser III in a nearby region, on the edge of the Amanos Mountains (Yamada 2000: 95).

The victory monuments of the Shalmanesser III were mostly seen along the Euphrates and Tigris Rivers, as recorded in his yearbooks. Birkleyn Relief is thought of as an example of rock reliefs of this king (Schachner 2009).

The Shalmanesser III, like his father the second Assurnasirpal, had a monolith built in Kurkh (Diyarbakir) region. The Shalmanesser III stated in his yearbooks that he had the Kurkh Monolith inscribed in about 853 BC. The area where Monolith stood, Ta'idu / Tidu, was defined as the Üçtepe region between Tuşhan and Sinamu on the edge of Upper Tigris River. Kurkh Monoliti, located in Üçtepe, provides information about the countries and the kings who were in contact. 
Y1ldırım, N. (2017). Inscribed triumphal columns of Assyrian kings in Anatolia as a symbol of sovereignty. International Journal of Social Sciences and Education Research, 3(4), 1112-1119.

Monolith describes the war between the Bìt-Adini and the Karkamis states, and it marks the political changes that took place as a result of this war. Towards the end of the monolith, the Shalmaneser's struggles against the alliance which was formed against him and included the king of Damascus Adad-idri, the king of Hamat Irhulini and the king of Israel Akhab were described. Both sides suffered heavy losses in this battle which is known as the War of Qarqar (north of Damascus) in the literature ( Smith 1938; Szuchman 2007).

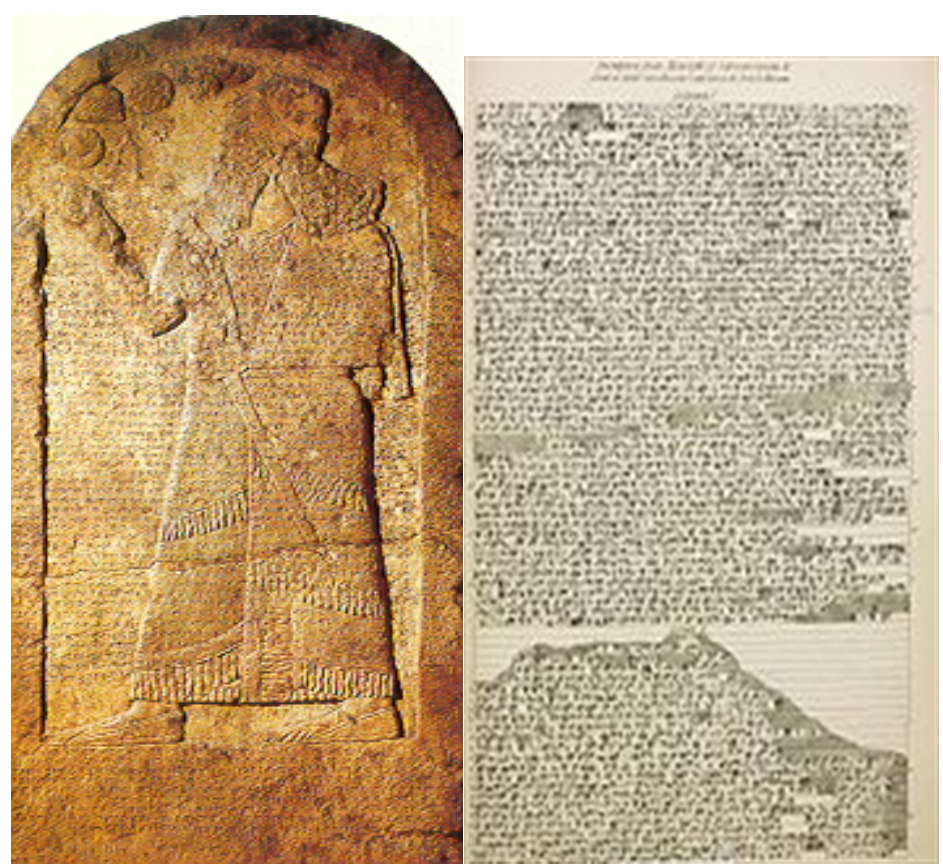

Shalmanesser III- Kurkh Monilith (British Museum)

The following lines are examples of recordings that will provide recognition of the Anatolian kingdoms and rulers in the Kurkh monolith and provide information about the Anatolian political profile:

KING
Sangara
Kundašpu
Arame
Lalla
Hayani(Hayya)
Qalparunda
Qalparunda

\section{COUNTRY}

Karkamıš ( ${ }^{\mathrm{m}} \mathrm{Sa} a$-an-ga-ra URU Gar-ga-miš- $a$-a $)$

Kummuh $\left({ }^{\mathrm{m}} K u-u n-d a-a ́ s ̌-p i\right.$ URU Ku-mu-ha-a-a)

Bīt-Agusi ( ${ }^{\mathrm{m}} A$-ra-me DUMU A-gu-si)

Melid ${ }^{\mathrm{m}} L a-l i$ URU Me-li-da-a-a)

Bit-Gabbari (Sam'al) ( ${ }^{\mathrm{m}} H a-i a-n i$ DUMU Ga-ba-ri)

Patına (Unqi) ( ${ }^{\mathrm{m}}$ Qàl-pa-ru-da KUR Pa-ti-na-a)

Gurgum $\left({ }^{\mathrm{m}}\right.$ Qàl-pa-ru-da KUR Gúr-gu-ma-a-a) 
Yildırım, N. (2017). Inscribed triumphal columns of Assyrian kings in Anatolia as a symbol of sovereignty. International Journal of Social Sciences and Education Research, 3(4), 1112-1119.

The Kenk Boğazı/ Kenk Gorge rock relief is another inscribed victory monument of the Shalmanesser III, which was reached from a region close to the north east of modern Gaziantep province. This rock relief, dated between 857-856 BC, had an important place in shedding light on the third Shalmanesser's campaigns throughout the Euphrates. The Shalmanesser III also mentioned the rebellion of King Ahuni of the Bït-Adini kingdom in Kenk Gorge and how he forced this king to submit.

This rock relief not only mentions the lands and the achievements of Shalmanesser, but also today's Eastern Anatolia (Turkey) geography was defined as Nairi and Urartu regions (Taşyürek 1979). The corresponding lines of the record contain the following statements:

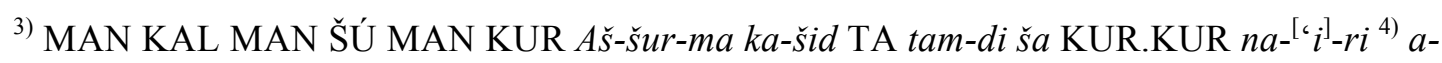

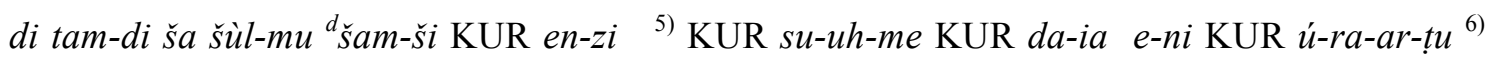
URU $m u-s ̦ a-s ̦ i-r u ~ . . .{ }^{\text {،3-6) }}$ Mighty King, King of the Universe, King of the land of Aššur; Conqueror from the Sea of the Na'iri-lands as far as The Sea of the Sunset, the land of Enzi, the land of Suhme, the land of Daiaeni, the land of Urartu, the city of Muṣașir..."

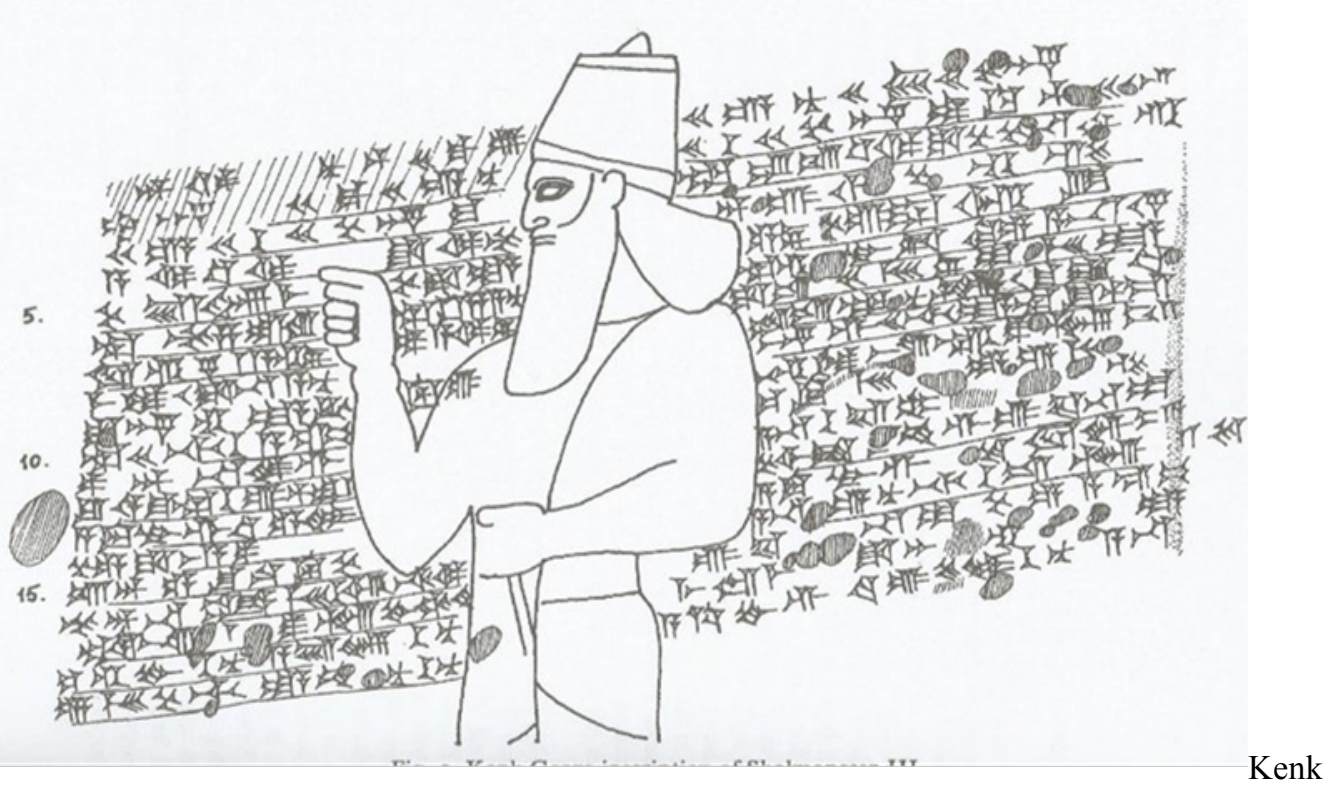

Gorge (III. Shalmanesser Rock Relief)

\section{Adad-Nerari III (810-783 BC)}

The Assyrian sovereignty throughout the Mediterranean also continued in the Adar-Nerari III period. The most important indicator of this is the stela, which is known in the literature as Antioch stela and was built in honor of the Adad-nerari III (Donbaz 1990: 5-7). This stela was approved by Šamšīilu, an administrative chief on behalf of the king. The Stel, in a traditional form, begins with the words "Adad-Nerari III is the great king, the mighty king, the king of the four worlds" (Galil 1992:58-59.) The Stela is about the border dispute between the Hamat region under King Zakur's control and Nahlasi region under King Ataršumki's control. When the stela is examined, it can be seen that an agreement was reached based on the principle of using Asi River jointly. This limit is indicated in the relevant lines of the stela as:

${ }^{4)}$ [ta]-hu-mu šá ina bir-ti za-ku-ri KUR ha-ma-ta-a-a ${ }^{5)}\left[\left(\right.\right.$ u ina) bir]-ti a-tar-šúm-ki $\mathrm{A}^{\mathrm{m}} a d-$ ramu ${ }^{\mathrm{m}}$ 10-ÉRIN.TÁH MAN KUR AŠ ${ }^{m}$ šamši-DINGIR LÚ tar-ta-nu ${ }^{6)}[i \check{s}-k u]-n u$-ni URU na- 
Yıldırım, N. (2017). Inscribed triumphal columns of Assyrian kings in Anatolia as a symbol of sovereignty. International Journal of Social Sciences and Education Research, 3(4), 1112-1119.

ah-la-si a-di A.ŠÀ.MEŠ-šú GIŠ.KIRI ${ }_{6}$.MEŠ-šú ${ }^{7)}$ ÍD ar-am-tú in abi-ri-šú-nu ${ }^{8)}[\dot{u}$-šam]-ši-lu-ma $i-z u-z u$ mi-șir .. " "4-8) The boundary which Adad-nērārī, king of the universe, king of Assyria, (and) Šamšīilu, the commender in chief, established between Zakur of the land of Hamath and Ataršumki, son of Adramu: the town of Nahlasi with all its fields, gardens, [and] settlements is (the property) of Ataršumki. They divided the Orontes River between them. This is the border..."

The last lines of the stela were inscribed to protect the stela: "The great gods of Assur, Aššur, Adad and Ber, Sin who has a temple in Harran, will not hear the prayers of those who make alterations on this stela."
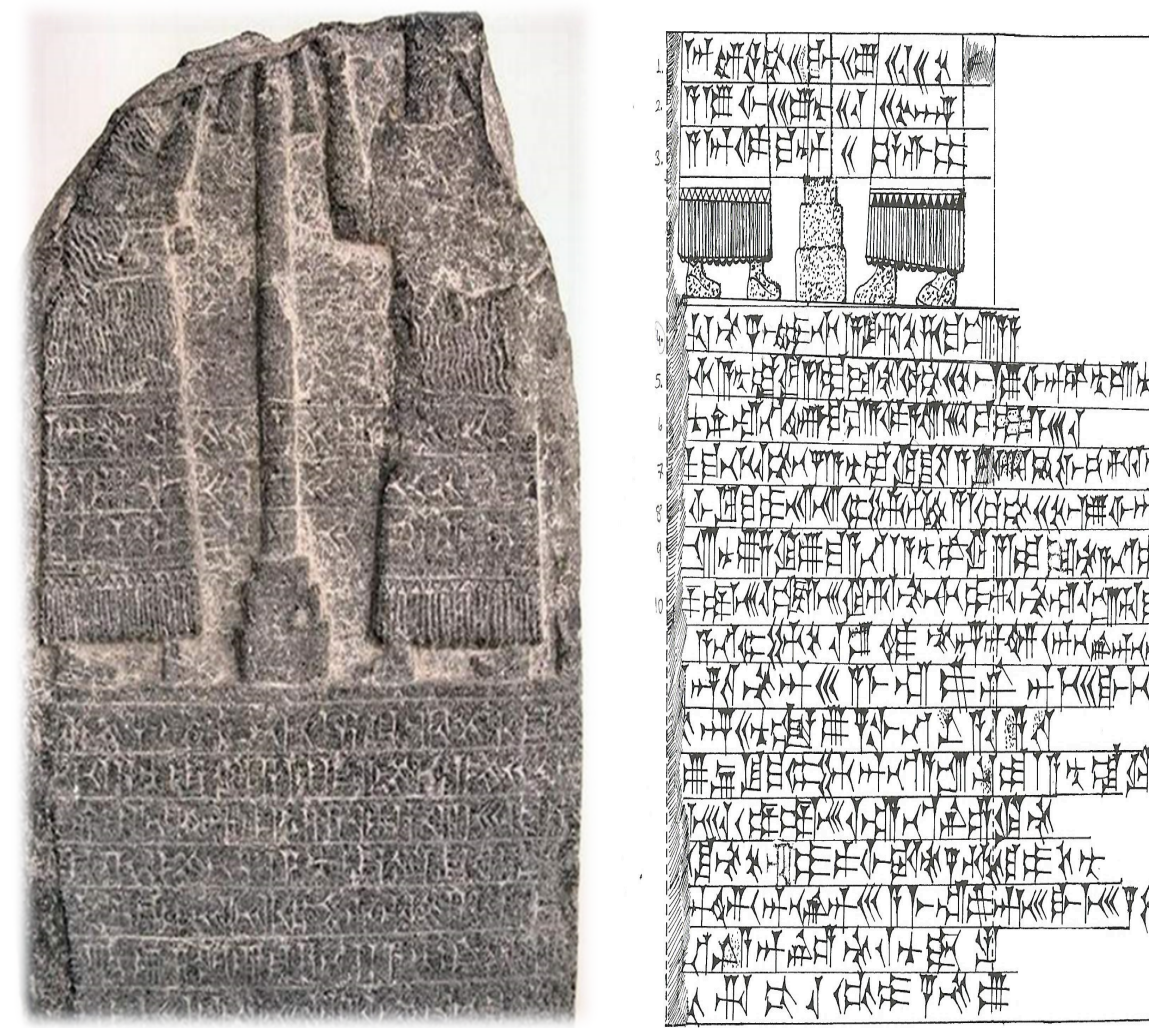

Antakya Stela

Another important inscribed stela dated to the third Adad-Nirari period is referred to as $\mathrm{Pa}$ zarcık Stela in the literature (Donbaz 1990: 9). This stela, which can be reached from near modern Kahramanmaras, recorded the name of the third Adad-Nirari's mother (Šammu-ramat) and the kings who formed a coalition against him. Related lines of the stela recorded the followings:

${ }^{7)}$.... ina $u_{4}-m e^{m} u \check{s}$-pi-lu-lu-me ${ }^{8)}$ MAN URU $k u-m u-h a-a-a a-n a{ }^{\mathrm{m}} 10$-ÉRIN.TÁH MAN KUR $a \check{s}$-šur ${ }^{9)}$ sa-am-mu-ra-mat MUNUS.É.GAL ${ }^{10)}$ ÍD pu-rat-tú ú-še-bi-ru-u-ni ${ }^{11)} a$-tar-šúm-ki A adra-a-me URU ár-pa-da-a-a ${ }^{12)} a$-di 8 MAN.MEŠ-ni šá KI-šú ina URU pa-qi-ra-hu-bu-na ... ${ }^{16)}$ ta-hu-mu šú-a-tú ina bir-ti ${ }^{m} u s ̌-p i-l u-l u-m e{ }^{17)}$ MAN URU ku-mu-ha-a-a ina bir-ti ${ }^{m} q a-a l-p a-r u-$ $d a(?)^{18)}$ A pa-la-lam MAN URU gúr-gu-ma-a-a ú-še-lu-ni ... “7-12) When Ušpilulume, king of the people of Kummuh, caused Adad-nērārī , king of Assyria, (and) Sammu-rāmat, the placewoman, to cross the Euphrates; I fought a pitched battle with them-with Ataršumki, son of 
Yildırım, N. (2017). Inscribed triumphal columns of Assyrian kings in Anatolia as a symbol of sovereignty. International Journal of Social Sciences and Education Research, 3(4), 1112-1119.

Adramu, of the city of Arpad(da), together with eight kings who were with him at the city Paqirahubuna..${ }^{16-18)}$ In this (same) year this boundary stone was set up between Ušpilulume, king of the people Kummuh, and Qalparuda, son of Palalam, king of the people of Gurgum..."
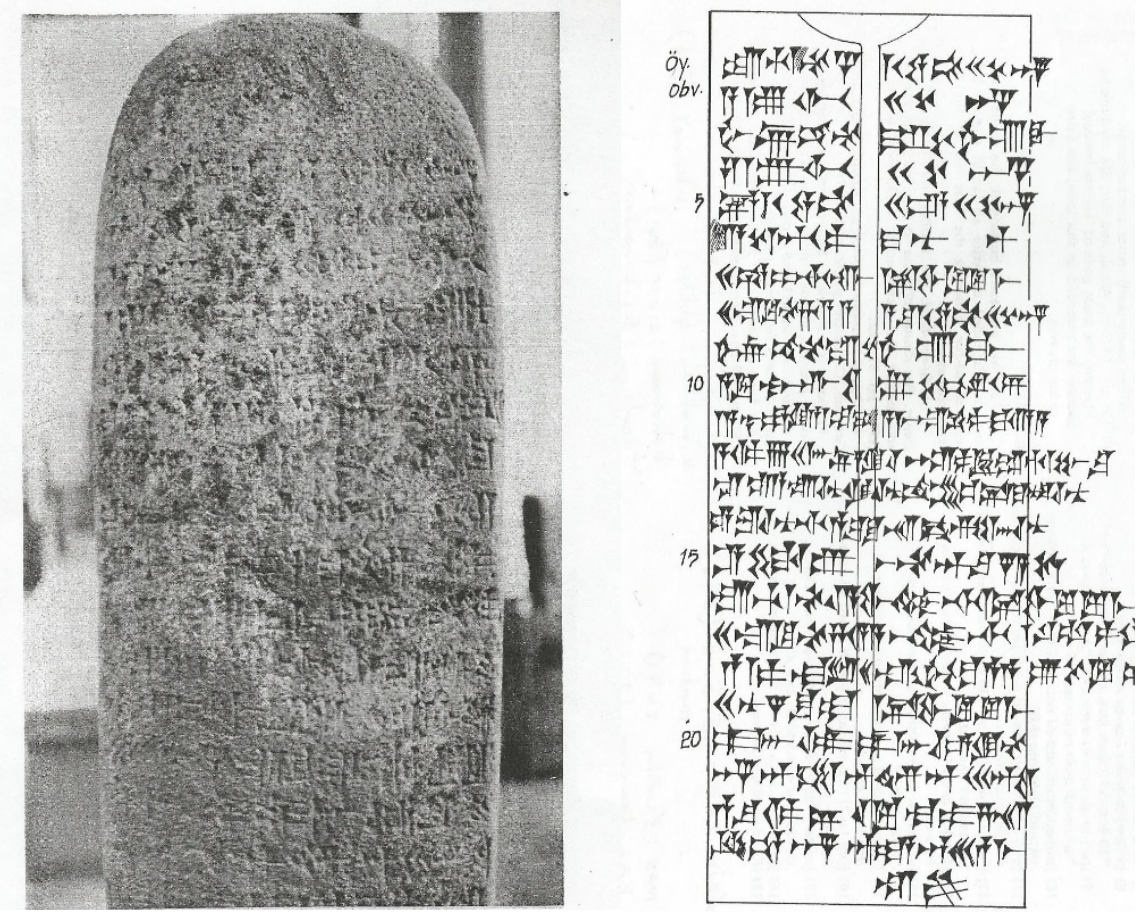

Pazarcık Stela

Ergani / Gisgis Relief of the Tiglat-Pileser III (745-727 BC) era (Köroğlu-Yumruk 2014: 27), Karabur Relief of unknown history (Taşyürek 1975: 176), Karkamish and Zincirli Stelas (Borger 1956-Yıldırım 2010: 122) of the Sargon II (722-705 BC) and Assarhaddon (681-669 BC) periods can be shown as the examples of uninscribed stelas and reliefs in Anatolia.

\section{Conclusion}

Seizing the rich raw material resources of Anatolia and gaining the superiority in the Mediterranean trade in this way has been one of the main reasons for the expeditions of the Assyrian kings. When the yearbooks of the Assyrian kings were examined, the aim to cross the Amanos Mountains and keep the small kingdoms of northern Syria under control is first observed. The existence of small kingdoms that do not pose danger in this geographical area ensured the main target of Assyria to be the Eastern Mediterranean coasts (Levantine), and therefore the sole controller of sea trade. The Anatolian and Eastern Mediterranean coasts, which are reached by following the rivers in general, especially the Euphrates and Asi Rivers, carried victory traces of the Assyrian kings. These traces can be found sometimes in inscribed or uninscribed stelas and sometimes in rock reliefs. These have been regarded as primary sources to shed light on the history of Anatolia and eastern Mediterranean of the first millennium, as well as being regarded as the most important indicators of the western expansionist policy that Assur had followed.

\section{References}

ARAB: Luckenbill,D.D. (1968). Ancient Records of Assyria and Babylonia,I- II, New York. 
Yildırım, N. (2017). Inscribed triumphal columns of Assyrian kings in Anatolia as a symbol of sovereignty. International Journal of Social Sciences and Education Research, 3(4), 1112-1119.

Borger, R. (1956). Die Inschriften Asarhaddons Königs von Assyrien, AfO, Beiheft 9, p. 1-133.

Donbaz, V. (1990). Two Neo-Assyrian Stelae in the Antakya and Kahramanmaraş Museums, Royal Inscriptions of Mesopotamia Project-ARRIM 8, p. 5-20, Toronto.

Galil, G. (1992). Conflicts Between Assyrian Vassals, $S A A B$ VI/1, p.52-63.

Günbattı, C. (1997). Kültepe'den Akadlı Sargon'a Ait Bir Tablet, Archivum Anatolicum 3, Ankara, p. 131-155.

Günbatt1, C. (2011). Anadolu'nun Politik Manzaras1, Arkeoatlas, 01, İstanbul 2011, p. 252-253.

Köroğlu. K.-Yumruk. Ş. (2014). Ergani/Gisgis (Kesentaş) Yeni Asur Kabartması, Türk Eskiçă̆ Bilimleri Enstitüsü Haberler 2014-38, İstanbul, p. 4-8.

Kulakoğlu, F. (2011). “Kültepe Kaniş Karumu: Anadolu’nun En Eski Uluslararası Ticaret Merkezi”, Anadolu'nun Önsözü Kültepe-Kaniš Karumu, K.B.Ş.B. Kültür Yayınları, İstanbul 2011, p.40-51.

Özgüç, T. (2005). Kültepe-Kaniş, Yapı Kredi Yayınları, İstanbul.

RIMA: K. Grayson (1991-1996) Assyrian Rulers of the Early First Millennium BC II (858-745 BC), Toronto.

Schacner, A. (2009). Assyriens Könige an einer der Quellen desTigris. Archaeologische Forschungen im Höhlensystem von Bırkleyn und am sogenannten Tigris-Tunnel, Tübingen: Ernst Wastmuth.

Smith, S. (1938). Assyrian Sculptures in the British Museum from Shalmaneser III to Sennacherib, London.

Szuchman, J.J. (2007). Ziyarettepe / Tušhan / Upper Tigris, London.

Taşyürek, A. O. (1975) . Some New Assyrian Rock-Reliefs in Turkey, Anatolian Studies, Vol. 25, p. 169180.

Taşyürek, A. O. (1979). A Rock Relief of Shalmaneser III on the Euphrates, Iraq 4, p. 47-53.

Ünal, A. (2006). “Hitit İmparatorluğu’nun Yıkılışından Bizans Dönemi’nin Sonuna Kadar Adana ve Çukurova Tarihi”, ÇÜ Sosyal Bilimler Enstitüsü Dergisi, 15-3 (Arkeoloji Özel Sayısı), p.67-102. Adana.

Weinfeld, M. (1999). Covenant Making in Anatolia and Mesopotamia”, XIV. Uluslararası Assriyoloji Kongresi, 6-10 / VII.

Yamada, S. (2000). The Construction of the Assyrian Empire, A Historical Study of the Inscriptions of Shalmanesser III (859-824 BC) Culture\&History of the Ancient Near East, Netherlands.

Yildırım, N. (2010). Anadolu'da Bulunan Yeni Asurca Belgeler, Ankara Üniversitesi Tarih Araştırmaları Dergisi, XXIX, 48, Ankara, p.119-135.

Yıldırım, N. (2016). Demir Çağında Anadolu'daki Aramiler'in Politik Coğrafyası, Cappadocian Journal of History and Social Sciences, Vol. 8, Ahlen-Germany, p. 120-137. 